V.V. Turov, V.M. Gun'ko, T.V. Krupska, M.T. Kartel

\title{
INFLUENCE OF SOLID AND LIQUID HYDROPHOBIC COMPOUNDS ON CHARACTERISTICS OF WATER LOCATED IN AN ADSORPTION LAYER OF A HYDROPHILIC COMPONENT OF THE SYSTEM
}

\author{
Chuiko Institute of Surface Chemistry of National Academy of Sciences of Ukraine \\ 17 General Naumov Str., Kyiv, 03164,Ukraine,E-mail:v_turov@ukr.net
}

\begin{abstract}
The aim of this study was to analyze the temperature and interfacial behavior of water bound to A-300, A-300/AM1 and $\mathrm{Al}_{2} \mathrm{O}_{3} / \mathrm{AM} 1$ initial and mechanically treated and located in air, chloroform alone or with addition of trifluoroacetic acid (TFAA) using low-temperature ${ }^{1} H N M R$ spectroscopy and cryoporometry. Properties of unmodified (A-300) and modified (AM1) (1:1) nanosilicas, as well as nanoalumina, were studied in air or chloroform alone or with addition of TFAA using ${ }^{1} H$ NMR spectra recorded at different temperatures and related cryoporometry. In nontreated composite, water interaction with nanosilica (hydration degree $h=1.125 \mathrm{~g} / \mathrm{g}$ ) increases and free surface energy $\gamma_{\mathrm{s}}$ grows by five times due to water reorganization into nanoclusters and similar clusters are absent in cA-300 due to several factors. After the mechanical treatment (bulk density increases to $\rho_{b} \approx 1.2 \mathrm{~g} / \mathrm{cm}^{3}$ ), water interaction energy with nanosilicas becomes smaller (by three times for $\mathrm{CDCl}_{3}$ and ten times for air medium) than that for nontreated composite. The effects of $\mathrm{CDCl}_{3}$ are much stronger for water in nontreated system than those in compacted composite. This is due to reorganization of water affected both by changes in the confined space effects and the influence of hydrophobic chloroform, which can displace water into small voids (inaccessible for larger chloroform molecules) or larger voids to reduce the contact area of both liquids. Thus, it has been shown that the observed influence of the hydrophobic components in complex hydrophobic/hydrophilic systems on enhancement of water binding to hydrophilic components is the general phenomenon caused by both the confined space effects and features of interactions of water with various hydrophobic structures such as the surface functionalities of hydrophobic silica and hydrophobic liquid (chloroform) or proton-donor components (TFAA).
\end{abstract}

Keywords: hydrophilic and hydrophobic nanosilicas, treated hydrated composites, ${ }^{1} \mathrm{H} N \mathrm{~N}$ spectra, confined space effects, bound water organization, freezing-melting point depression

\section{INTRODUCTION}

Various blends of hydrophilic and hydrophobic matters, e.g. powders, polymers, etc., are of interest from a practical point of view [1-9] because they can strongly reorganize water structure [10-15] and affect the properties of whole materials such as «dry water» powders or various emulsions [3-9]. The interfacial behavior of water bound to a hydrophilic component of hydrophilic-hydrophobic systems depends on structure of hydrophilic and hydrophobic components and dispersion media [12-15]. Confined space effects (i.e. pore morphology and structure of pore walls) in pure hydrophilic or hydrophobic systems differ from those in hydrophobic/hydrophilic blends $[12,13]$. Additionally, hydrophobic media (e.g. nonpolar or weakly polar liquids such as $n$-decane, benzene, chloroform, etc.) can strongly affect the water organization in the complex systems. The main driving forces of water reorganization in these systems are linked to a criterion of necessary minimization of contact area between water and hydrophobic components, both solid and liquid. Mechanical treatment of complex systems can result in changes in the structure of solid components (e.g. highly disperse ones) and, therefore, in the organization of bound water. These effects could be maximal for nanostructured systems (such as fumed metal or metalloid oxides, FMO) because even low mechanical loading can lead to strong changes in the organization of hydrophilic/hydrophobic FMO nanopowders.

Fumed nanosilica A-300 composed of nonporous nanoparticles (NPNP) of $c a .9-10 \mathrm{~nm}$ in average diameter (specific surface area $\left.S_{\mathrm{BET}} \approx 300 \mathrm{~m}^{2} / \mathrm{g}\right)$ has surface silanols $\left(\sim 2-4 \mathrm{OH} / \mathrm{nm}^{2}\right)$ providing hydrophilic properties of the material $[1,2]$. Complete hydro- 
phobization of A-300 by silanes used to replace the $\mathrm{SiOH}$ groups by trimethylsilyl (TMS) or dimethylsilyl (DMS) groups leads to a small diminution of the $S_{\mathrm{BET}}$ value and to a small increase in the size of NPNP. Typically, NPNP of FMO form aggregates $(<1 \mu \mathrm{m}$ in size $)$ and loose agglomerates of aggregates $(>1 \mu \mathrm{m})$ $[1,2,16]$, and the initial powder has low bulk density $\rho_{\mathrm{b}} \approx 0.05-0.10 \mathrm{~g} / \mathrm{cm}^{3}$. Bonding of NPNP in aggregates and agglomerates is occurred due to electrostatic and van-der-Waals forces, practically, without chemical bonds between NPNP adjacent in the secondary structures. Therefore, these secondary particles can be easily decomposed in the aqueous media or reorganized upon wetting-drying or lowmechanical loading (hand pressing, grinding in a mortar, ball-milled, etc.) [13]. Note that wetting of hydrophobic fumed silica (e.g. AM1) by nonpolar liquids (e.g. hexane) and drying results in much smaller compaction of the powder. The aim of this study was to analyze the temperature and interfacial behavior of water bound to A300, A-300/AM1 and $\mathrm{Al}_{2} \mathrm{O}_{3} / \mathrm{AM} 1$ initial and mechanically treated and located in air, chloroform alone or with addition of trifluoroacetic acid (TFAA) using lowtemperature ${ }^{1} \mathrm{H} N M R$ spectroscopy and cryoporometry.

\section{EXPERIMENTAL AND COMPUTATIONAL METHODS}

Fumed silicas, initial hydrophilic (A-300 with specific surface area $S_{\mathrm{BET}}=295 \mathrm{~m}^{2} / \mathrm{g}$, bulk density $\left.\rho_{\mathrm{b}}=0.05 \mathrm{~g} / \mathrm{cm}^{3}\right)$, fumed alumina $\left(S_{\mathrm{BET}}=89 \mathrm{~m}^{2} / \mathrm{g}\right.$, bulk density $\left.\rho_{\mathrm{b}}=0.07 \mathrm{~g} / \mathrm{cm}^{3}\right)$, and modified (AM1, $S_{\mathrm{BET}}=285 \mathrm{~m}^{2} / \mathrm{g}$, A-300 was hydrophobized using dimethyldichlorosilane) A-300 samples (Pilot plant of Chuiko Institute of Surface Chemistry, Kalush, Ukraine), were used to prepare composites. Before the use, hydrophilic nanosilica was wetted and dried that resulted in increased bulk density of the powder to $\rho_{\mathrm{b}} \approx 0.3 \mathrm{~g} / \mathrm{cm}^{3}$ (compacted silica cA-300). Hydrophobic AM1 was used as received. A blend of A-300 (or alumina) and AM1 (1:1) was prepared by careful grinding of them in a porcelain mortar for $10 \mathrm{~min}$ that gives dry powder at $\rho_{\mathrm{b}} \approx 0.14 \mathrm{~g} / \mathrm{cm}^{3}$. To prepare hydrated powders, $1.125 \mathrm{~g}$ (or $0.5 \mathrm{~g}$ for alumina) of distilled water was added to cA-300 or cA-300/AM1 and mixed without mechanical loading that gives the mixtures with $\rho_{\mathrm{b}} \approx 0.6$ and $0.3 \mathrm{~g} / \mathrm{cm}^{3}$, respectively. Then hydrated cA300/AM1 was carefully grinded in the porcelain mortar to form a dense composite (additionally pressed in a NMR ampoule) at $\rho_{\mathrm{b}} \approx 1.2 \mathrm{~g} / \mathrm{cm}^{3}$.

Microphotographs (Primo Star optical microscope, Carl Zeiss) of used samples show some structural features of them.

${ }^{1} \mathrm{H}$ NMR spectra of static samples (placed into 4 and $5 \mathrm{~mm}$ NMR ampoules) hydrated at $h=1.125 \mathrm{~g} \mathrm{H}_{2} \mathrm{O}$ per gram of dry silicas in air or chloroform media (alone or with addition of trifluoroacetic acid, TFAA) were recorded using a Varian 400 Mercury spectrometer (magnetic field $9.4 \mathrm{~T}$, bandwidth $20 \mathrm{kHz}$ ) utilizing eight $90^{\circ}$ pulses of $3 \mu$ s duration. Each spectrum was recorded by co-addition of eight scans with $2 \mathrm{~s}$ delay between each scan. Relative mean errors were less than $\pm 10 \%$ for ${ }^{1} \mathrm{H}$ NMR signal intensity for overlapped signals, and $\pm 5 \%$ for single signals. Temperature control was accurate and precise to within $\pm 1 \mathrm{~K}$. The accuracy of integral intensities was improved by compensating for phase distortion and zero-line nonlinearity with the same intensity scale at different temperatures. To prevent supercooling, spectra were recorded starting at $T=200-210 \mathrm{~K}$ for samples precooled to this temperature for $10 \mathrm{~min}$. Samples were heated to $285 \mathrm{~K}$ at a rate of $5 \mathrm{~K} / \mathrm{min}$ with steps $\Delta T=10 \mathrm{~K}$ or $5 \mathrm{~K}$ (with a heating rate of $5 \mathrm{~K} / \mathrm{min}$ for $2 \mathrm{~min}$ ), and maintained at a fixed temperature for $8 \mathrm{~min}$ for data acquisition at each temperature. The measurements were carried out in various dispersion media such as air, chloroform-d alone or with addition of TFAA $(5: 1)$. Small addition of acetone (and tetramethylsilane) to $\mathrm{CDCl}_{3}$ was used as a standard of the chemical shift of the proton resonance $\delta_{\mathrm{H}}=2 \mathrm{ppm}$ for acetone with respect to tetramethylsilane ( $\left.\delta_{\mathrm{H}}=0 \mathrm{ppm}\right)$.

Changes in the Gibbs free energy $(\Delta G)$ of bound water were determined from the temperature dependences of the amounts of unfrozen water $\left(C_{\text {uw }}\right.$ in $\mathrm{mg}$ of water per gram of dry sample) at $T=200-273 \mathrm{~K}$ [13] and tabulated $\Delta G$ data for ice. The area under the $\Delta G\left(C_{\text {uw }}\right)$ curve determines interfacial Gibbs free energy (the modulus of overall changes in the Gibbs free energy of bound water due to interaction with a surface) 
$\gamma_{S}=-A \int_{0}^{C_{u x}^{\max }} \Delta G\left(C_{u w}\right) d C_{u w}$,

where $C_{u w}^{\max }$ is the total amount of unfrozen water at $T=273 \mathrm{~K}$, and $A(>0)$ is a constant dependent on the type of units used in this equation. The average melting temperature $\left\langle T_{\mathrm{m}}>\right.$ was calculated using formula [13]

$<T_{m}>=\int_{T_{\min }}^{T_{0}} T C_{u w}(T) d T / \int_{T_{\min }}^{T_{0}} C_{u w}(T) d T$,

where $T_{0}=273.15 \mathrm{~K}$, and $T_{\min }$ is the temperature corresponding to $C_{\mathrm{uw}}=0$.

Applications of this method and NMR cryoporometry to nanooxides were described in detail elsewhere [13]. Note that signals of immobile (frozen or representing macrostructures) molecules and functionalities of particles were not registered due to a narrow bandwidth $(20 \mathrm{kHz})$ and the use of static samples. Changes in the Gibbs free energy $(\Delta G)$ of bound water were determined from the temperature dependences of the amounts of unfrozen water $\left(C_{\mathrm{uw}}\right.$ in $\mathrm{mg}$ of water per gram of dry sample) at $T=200-273 \mathrm{~K}$ [13] and tabulated $\Delta G$ data for ice. The area under the $\Delta G\left(C_{\mathrm{uw}}\right)$ curve determines interfacial Gibbs free energy (the modulus of overall changes in the Gibbs free energy of bound water due to interactions with a surface) $[12,13]$. Water can be frozen in narrower pores (or voids between nanoparticles) at lower temperatures as described by the Gibbs-Thomson relation for the freezing point depression for liquids confined in cylindrical pores at radius $R[13,17-19]$.

$\Delta T_{m}=T_{m}(R)-T_{m, \infty}=\frac{2 \sigma_{s l} T_{m, \infty}}{\Delta H_{f} \rho R}=-\frac{k_{G T}}{R}$,

where $T_{\mathrm{m}}(R)$ is the melting temperature of a frozen liquid in pores of radius $R, T_{\mathrm{m}, \infty}$ the bulk melting temperature, $\rho$ the density of the solid, $\sigma_{\mathrm{sl}}$ the energy of solid-liquid interaction, $\Delta H_{\mathrm{f}}$ the bulk enthalpy of fusion, $k_{\mathrm{GT}}$ is a constant, and for water bound to nanosilica $k_{\mathrm{GT}}=67 \mathrm{~K} \cdot \mathrm{nm}$. Differential size distribution of unfrozen water structures can be calculated as follows [13]:

$\frac{d V_{u w}(R)}{d R}=\frac{A}{k_{G T}}\left(T_{m}(R)-T_{m, \infty}\right)^{2} \frac{d C_{u w}(T)}{d T}$, where $V_{\text {uw }}(R)$ is the volume of unfrozen water in pores of radius $R, C_{\mathrm{uw}}$ the amount of unfrozen water per gram of adsorbent as a function of temperature, and $A$ is a constant.

The $f_{\mathrm{V}}(R)=d V / d R$ function can be converted into the distribution function $f_{\mathrm{S}}(R)$ with respect to the specific surface area in contact with unfrozen water or other liquids [13]

$f_{S}(R)=\frac{w}{R}\left(f_{V}(R)-\frac{V(R)}{R}\right)$,

where $w=1,2$ and 1.36 for slitshaped, cylindrical pores and voids between spherical particles packed in the cubic lattice, respectively. Integration of the $f_{\mathrm{V}}(R)$ and $f_{\mathrm{S}}(R)$ functions at $R<1 \mathrm{~nm}, \quad \quad 1 \mathrm{~nm}<R<25 \mathrm{~nm}, \quad$ and $25 \mathrm{~nm}<R<100 \mathrm{~nm}$ gives the volume and the specific surface area of nano-, meso- and macropores. The specific surface area $\left(S_{\text {uw }}\right)$ of adsorbents in contact with bound water (assuming for simplicity that the density of unfrozen bound water $\rho_{\mathrm{uw}}=1 \mathrm{~g} / \mathrm{cm}^{3}$ ) can be determined from the amount of this water $C_{u w}^{\max }$ (estimating pore volume as $V_{\mathrm{uw}}=C_{u w}^{\max } / \rho_{\mathrm{uw}}$ ) at $T=273.15 \mathrm{~K}$ and pore size distribution $f(R)$ (used to estimate the average pore radius $R_{\mathrm{av}}$ ) with a model of cylindrical pores [13]:

$S_{u w}=\frac{V_{u w}}{2 R_{a v}}=\frac{2 C_{u w}^{\max }}{\rho_{u w}} \int_{R_{\min }}^{R_{\max }} f(R) d R / \int_{R_{\min }}^{R_{\max }} f(R) R d R$,

where $R_{\min }$ and $R_{\max }$ are the minimal and maximal radii of pores filled by unfrozen water, respectively. In the case of calculations of the structural characteristics of nanopores $(R<1 \mathrm{~nm})$, mesopores $(1 \mathrm{~nm}<R<25 \mathrm{~nm})$ and macropores $(R>25 \mathrm{~nm})$, the $R_{\min }$ and $R_{\max }$ values are the boundary $R$ values for the corresponding pore types (including $R_{\min }=0.2 \mathrm{~nm}$ for nanopores), and the $C_{u w}^{\max } / \rho_{u w}$ value should be replaced by the corresponding values of the volumes of nanopores, mesopores, or macropores.

The $\delta_{\mathrm{H}}(T)$ function depends on the number of possible configurations of the water molecules in the hydrogen bonds network strongly affected by solutes, functionalized surface, and dispersion media $[12,13]$. This number is inversely proportional to the average number of the hydrogen bonds $\left\langle n_{\mathrm{HB}}\right\rangle$, according to the hydrogen bond entropy definition $S \approx-k_{B} \ln n_{\mathrm{HB}}$ 
[20]. Therefore, the temperature derivative of the measured fractional chemical shift [20]

$$
-\left(\frac{\partial \ln \delta(T)}{\partial T}\right)_{p}=-\left(\frac{\partial \ln <n_{H B}>}{\partial T}\right)_{p} \approx\left(\frac{\partial S}{\partial T}\right)_{p}
$$

should be proportional to the constant pressure specific heat $C_{\mathrm{P}}(T)\left(C_{\mathrm{P}}=T(\partial S / \partial T)_{\mathrm{P}}\right)$.

Quantum chemical calculations of relatively small models $(<400$ atoms) were carried out using density functional theory (DFT) method with a hybrid functional $\omega$ B97X-D [21-23] (labeled as wB97XD in Gaussian 09) with the cc-pVDZ basis set using the Gaussian 09 program suit [21]. The solvation effects were analyzed using the solvation method SMD [24] implemented in Gaussian 09. The gaugeindependent atomic orbital (GIAO) method [21] was used to calculate the NMR spectra of certain water clusters (up to $100 \mathrm{H}_{2} \mathrm{O}$ ). Larger models (up to 15000 atoms) were calculated using the PM7 method with the MOPAC 2016 program suit $[25,26]$. Visualization of the calculated structures was carried out using GaussView 5.09 [27], ChemCraft [28] or Chimera [29] program suits.

The $\delta_{\mathrm{H}}$ values were calculated as the difference in the isotropic values of the magnetic shielding tensors of $\mathrm{H}$ atoms $\left(\sigma_{\mathrm{H}, \text { iso }}\right)$ of tetramethylsilane, TMS $\left(\delta_{\mathrm{H}, \mathrm{TMS}}=0 \mathrm{ppm}\right)$ as a reference compound (e.g. $\sigma_{\mathrm{H}, \text { iso }}=31.76$ and $31.40 \mathrm{ppm}$ for TMS by GIAO/B3LYP/6-31G(d,p) and $\mathrm{GIAO} / \omega \mathrm{B} 97 \mathrm{X}-\mathrm{D} / \mathrm{cc}-\mathrm{pVDZ}$, respectively) and a given compound using equation [21]

$\delta_{\mathrm{H}}=\frac{1}{3} \operatorname{Tr} \sigma_{\mathrm{H}, \mathrm{TMS}}-\frac{1}{3} \operatorname{Tr} \sigma_{\mathrm{H}}$.

where $\operatorname{Tr}$ is the trace of matrix, since $\sigma$ is the tensor with nine elements. The distribution functions of the $\delta_{\mathrm{H}}$ values were calculated using a simple equation [13]

$f\left(\delta_{\mathrm{H}}\right)=\left(2 \pi \sigma^{2}\right)^{-0.5} \sum_{j} \exp \left[-\left(\delta_{j}-\delta_{\mathrm{H}}\right)^{2} / 2 \sigma^{2}\right]$,

where $j$ is a number of $\mathrm{H}$ atom, $\sigma^{2}$ is the distribution dispersion, and $\delta_{j}$ is the calculated value of the $j$-th $\mathrm{H}$ atom. To calculate the $f\left(\delta_{\mathrm{H}}\right)$ functions using the PM7 results, a calibration function was used to describe the dependence between atomic charges $q_{\mathrm{H}}(\mathrm{PM} 7)$ and the $\delta_{\mathrm{H}}$ values $(\mathrm{GIAO} / \omega \mathrm{B} 97 \mathrm{X}-\mathrm{D} / \mathrm{cc}-\mathrm{pVDZ})$ for water clusters $\left(\delta_{\mathrm{H}}=-27.38435372+83.67491184 \times q_{\mathrm{H}}\right)$.
This function was used to calculate the ${ }^{1} \mathrm{H}$ NMR spectra of water clusters bound to silicas.

\section{RESULTS AND DISCUSSION}

The ${ }^{1} \mathrm{H}$ NMR spectra of water bound to A-300 or A-300/AM1 mechanically nontreated (Fig. 1) or treated (Figs. 2 and 3) show (Fig. 4) a decrease in signal intensity and a certain downfield shift with decreasing temperature.

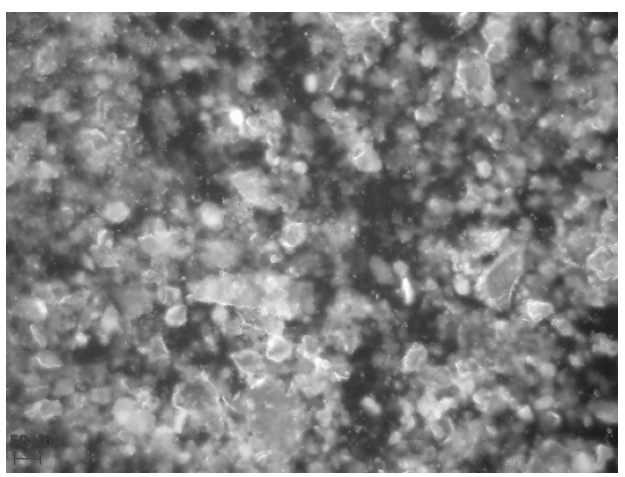

Fig. 1. Initial composite of cA-300/AM1 without mechanical treatment
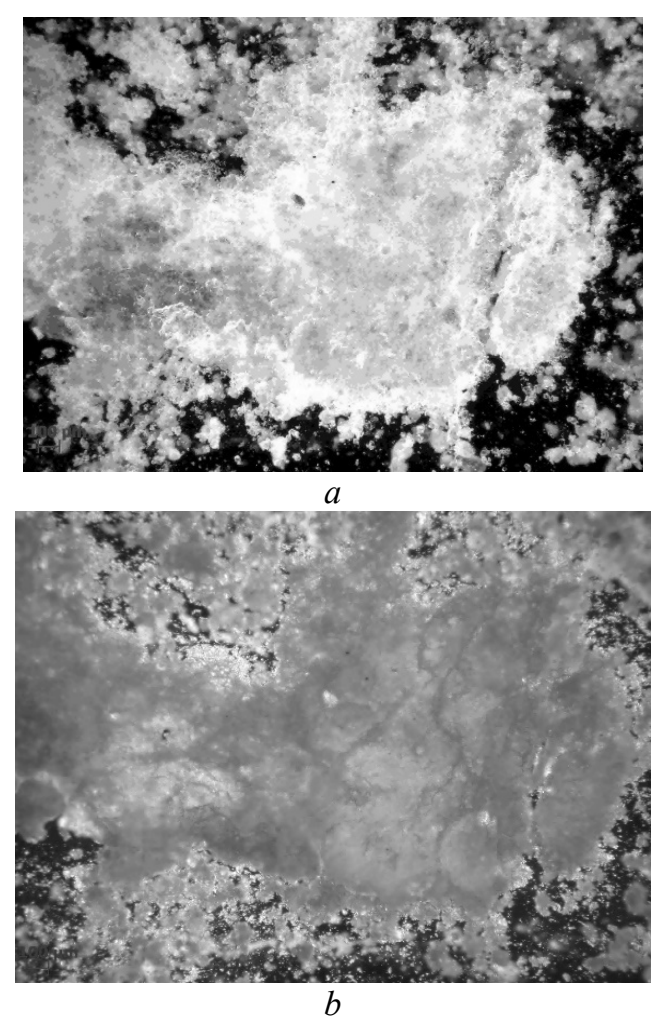

Fig. 2. Treated hydrated cA-300/AM1 composite in (a) reflectance and $(b)$ transmittance mode 
Both effects are due to freezing-out of weakly bound water (WBW, Table 1, $C_{\mathrm{uw}}{ }^{\mathrm{w}}$ ) at $260 \mathrm{~K}<T<273 \mathrm{~K}$ and freezing-out of strongly bound water (SBW, Table 1, $C_{\text {uw }}{ }^{\mathrm{s}}$ ) at lower temperatures $T<260 \mathrm{~K} \quad$ (Fig. 5). Stronger hydrogen bonds of water molecules with surface silanols (Gibbs free energy of adsorbed water $\Delta G<0$ ) than those with other water molecules and the effects of the electrostatic field of silica cause greater deshielding of the protons of SBW than that of WBW or bulk water [13].

Similar effects are observed for mixtures of hydrophilic fumed alumina and hydrophobic AM1 in air, hydrophobic chloroform alone or with addition of strongly hydrophilic TFAA (Fig. 6). Thus, the hydrophobic components $\left(\mathrm{AM} 1, \mathrm{CDCl}_{3}\right.$ ) of the systems enhance the water binding in the hydrophilic alumina.

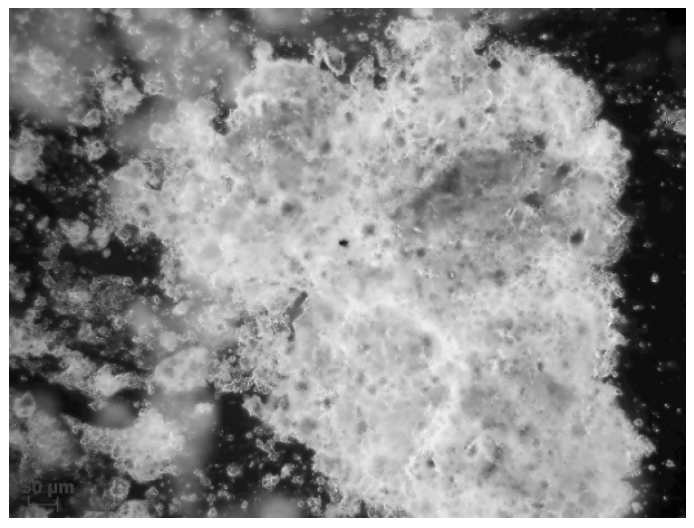

$a$

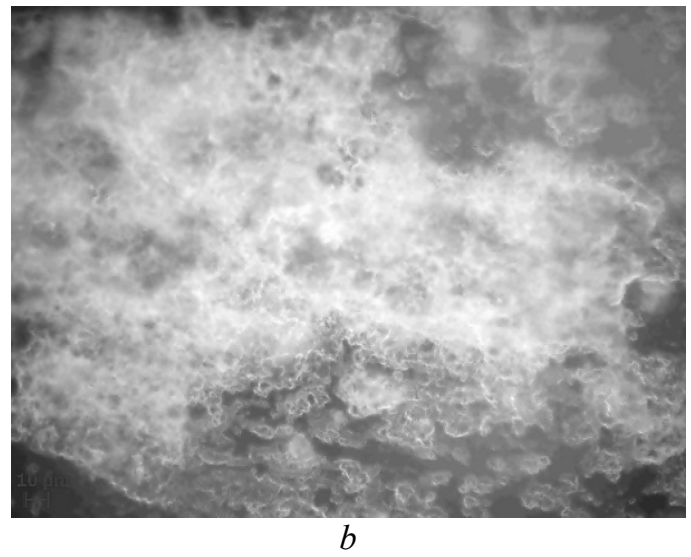

Fig. 3. Treated hydrated cA-300/AM1 composite in reflectance mode of different magnification scale bar of $50(a)$ and $10 \mu \mathrm{m}(b)$

The amount of SBW significantly increases for untreated cA-300/AM1 (in air) in comparison with cA-300 in air (Fig. 5, Table 1). This leads to a decrease in $\Delta G_{\mathrm{s}}$ (changes in the Gibbs free energy of SBW) and increase in $\gamma_{\mathrm{S}}$ (Table 1), and the average melting temperature $<T_{\mathrm{m}}>$ decreases by $11.4 \mathrm{~K}$, but the $\delta_{\mathrm{H}}$ values decrease (Fig. $7 a$ ). The main reason of these effects is the changes in the organization of unfrozen water (Table $1, S$ and $V$, Fig. 8) with an increase in contributions of nanostructures $(R<1 \mathrm{~nm})$ and mesostructures $(1 \mathrm{~nm}<R<25 \mathrm{~nm})$. The latter is well observed in the differential unfrozen water cluster size distributions (UWCSD) (Fig. $8 a$, curves 1 and 2).

If the dispersion medium is weakly polar $\left(\mathrm{CDCl}_{3}\right)$, then the organization of water bound to untreated cA-300/AM1 strongly changes since water tends to decrease the contact area with chloroform (because water and chloroform are immiscible liquids). This can be provided by an increase in the size of water clusters/domains having smaller surface area than smaller clusters (Table 1, $S$ and $V$ ) or location of water molecules in pores (voids) inaccessible for larger $\mathrm{CDCl}_{3}$ molecules [13].

In the case of treated cA-300/AM1 located in air, the water organization (e.g. SBW/WBW ratio, the $S$ and $V$ values, $<T_{\mathrm{m}}>, \gamma_{\mathrm{s}}, \Delta G_{\mathrm{s}}$, Table 1) is similar to that of water bound to cA-300 alone (Table 1, Figs. 4-8) despite strong compaction of the system upon mechanical treatment and the presence of hydrophobic AM1. For the latter, the $\delta_{\mathrm{H}}$ values decrease but entropy increases (Fig. 7 , curves 1 and 4). The samples with mechanically nontreated and treated cA-300/AM1 located in air are strongly different. Compaction of the composite leads to a decrease in the amounts of SBW, $\gamma_{\mathrm{S}}$ value, and contribution of small water clusters (Fig. 8, curves 2 and 4). This system could represent AM1 aggregates (cores) surrounded by hydrated cA-300 aggregates (shells), i.e., compacted core-shell agglomerates are formed (Fig. 9, inserts). The amount of residual air bubbles in this system is small (since $\rho_{\mathrm{b}} \approx 1.2 \mathrm{~g} / \mathrm{cm}^{3}$ and possible true density of cA-300/AM1 at $h=1.125 \mathrm{~g} / \mathrm{g}$ could be $\sim 1.54 \mathrm{~g} / \mathrm{cm}^{3}$, and segregation of hydrophilic and hydrophobic silicas is not observed in the aqueous media).

Nontreated cA-300/AM1 composite easily wetted by chloroform can form stable suspension (without segregation) in chloroform. Chloroform can displace small water clusters from relatively narrow voids between NPNP, water forms larger structures (Fig. 8), and the water interaction energy with nanosilica decreases (Table $1, \gamma_{\mathrm{S}}$ ). The chloroform effects for mechanically treated 
composite are much smaller (Figs. 5-8, curves 4 and 5, Table 1) than those for nontreated composite (curves 2 and 3 ). This difference is due to several factors: (i) $\rho_{\mathrm{b}}$ increases and empty volume (voids between NPNP filled by water

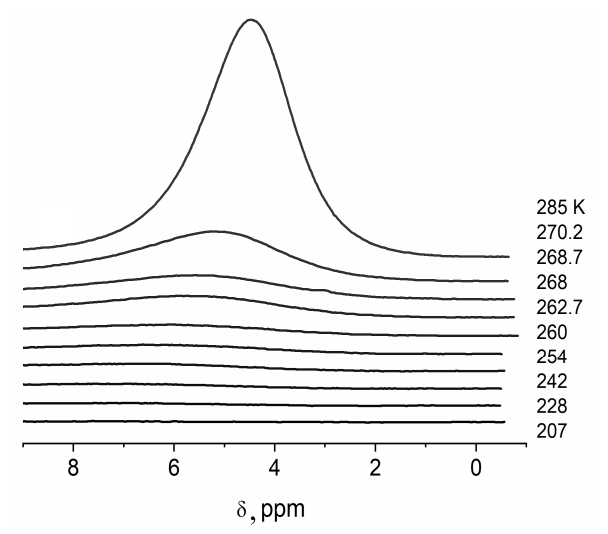

$a$
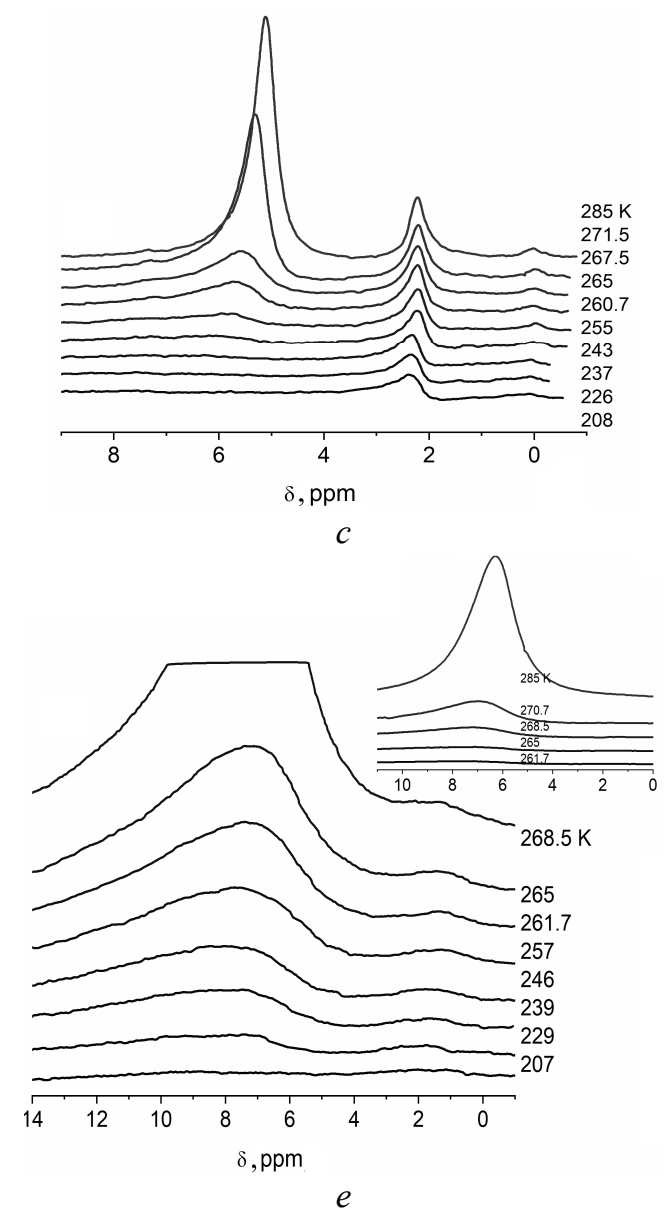

or/and chloroform) decreases; (ii) core-shell agglomerates are formed during mechanical treatment of the mixture; (iii) accessibility of narrow voids for chloroform molecules decreases.

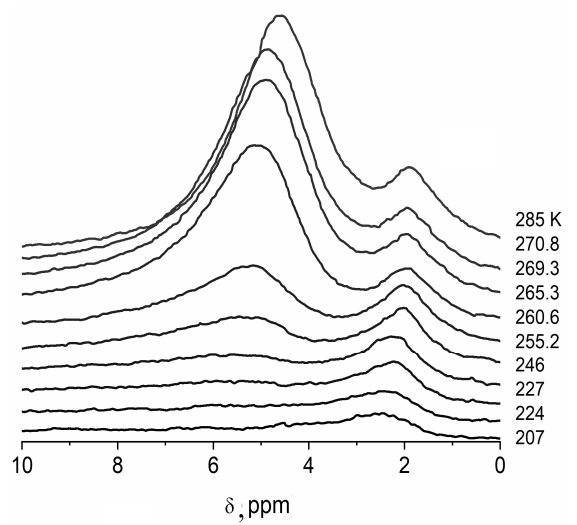

$b$
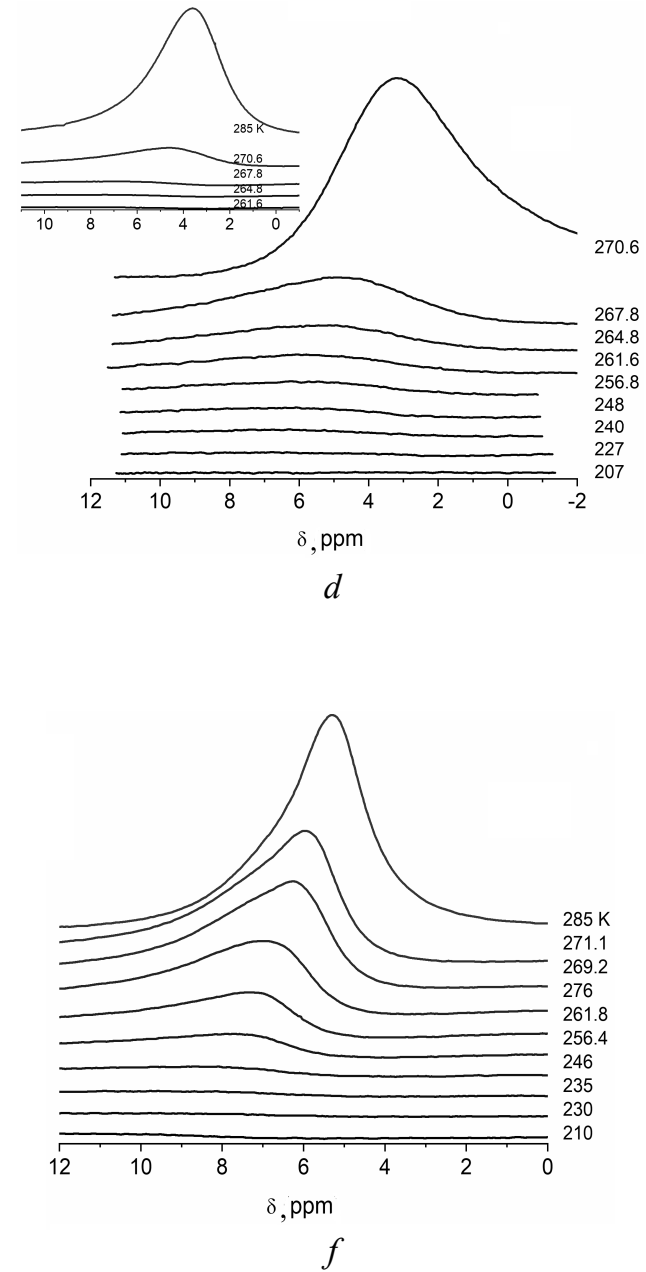

Fig. 4. ${ }^{1} \mathrm{H}$ NMR spectra recorded at different temperatures for samples at constant $h=1.125 \mathrm{~g} / \mathrm{g}(a)$ cA-300 in air, nontreated cA-300/AM1 in $(b)$ air and $(c) \mathrm{CDCl}_{3}$ (with addition of acetone and TMS), mechanically treated $\left(\rho_{\mathrm{b}} \approx 1.2 \mathrm{~g} / \mathrm{cm}^{3}\right)$ cA-300/AM1 located in $(d)$ air, $(e) \mathrm{CDCl}_{3}$, and $(f)$ 5CDCl $3 / 1 \mathrm{TFAA}$ (signals at 0 and $2 \mathrm{ppm}$ are due to added tetramethylsilane and acetone, respectively) 


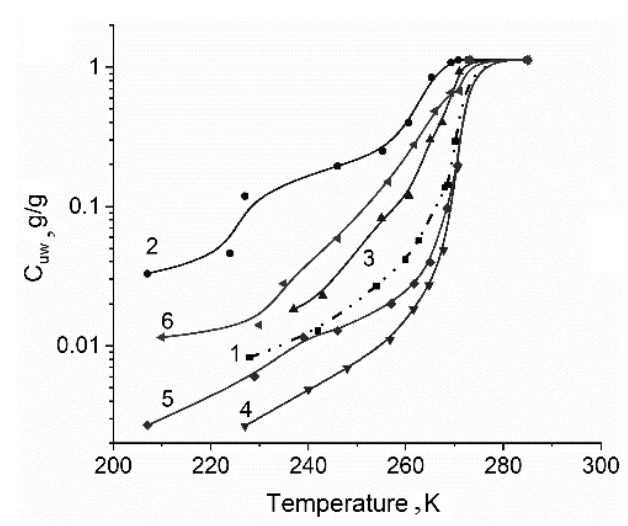

$a$

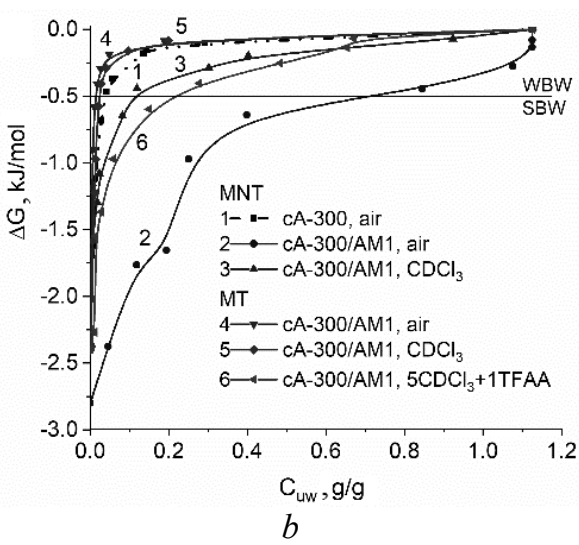

Fig. 5. (a) Dependence of the amounts of unfrozen water $C_{\mathrm{uw}} v s$. temperature and $(b)$ relationship between the $C_{\mathrm{uw}}$ values and changes in the Gibbs free energy of water bound in samples (at constant $h=1.125 \mathrm{~g} / \mathrm{g}$ for all samples): (curve 1) cA-300 in air, non-treated (MNT) cA-300/AM1 in (2) air and (3) $\mathrm{CDCl}_{3}$, mechanically treated $(\mathrm{MT})\left(\rho_{\mathrm{b}} \approx 1.2 \mathrm{~g} / \mathrm{cm}^{3}\right) \mathrm{cA}-300 / \mathrm{AM} 1$ in (4) air, (5) $\mathrm{CDCl}_{3}$, and (6) $5 \mathrm{CDCl}_{3} / 1 \mathrm{TFAA}$

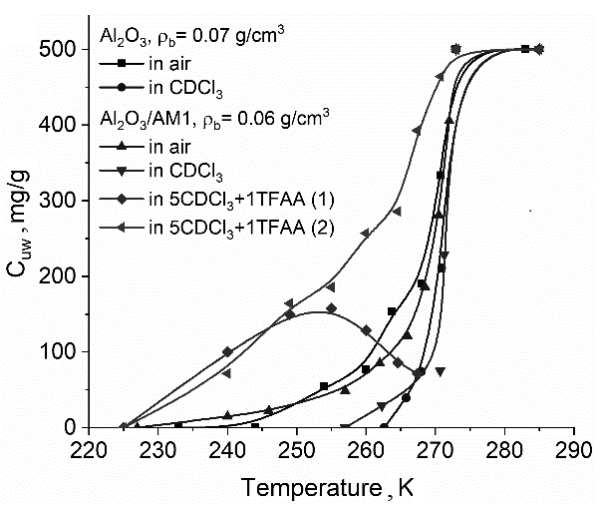

$a$

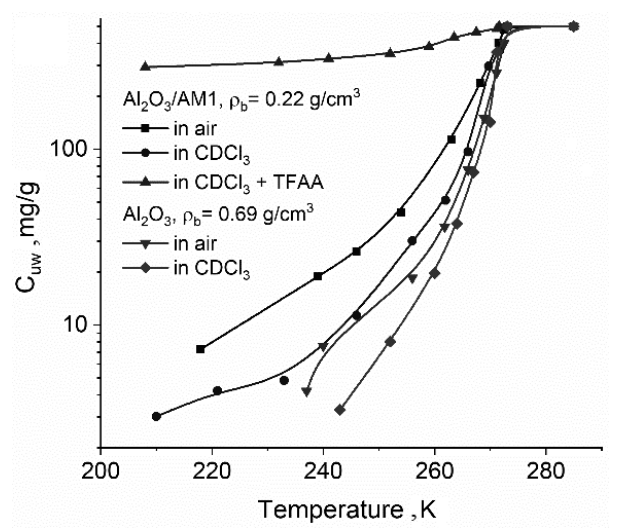

$b$

Fig. 6. Dependence of the amounts of unfrozen water $C_{\text {uw }} v s$. temperature in $\mathrm{Al}_{2} \mathrm{O}_{3}$ and $\mathrm{Al}_{2} \mathrm{O}_{3} / \mathrm{AM} 1$ (at constant $h=0.5 \mathrm{~g} / \mathrm{g}$ for all samples) (a) non-treated and $(b)$ treated samples located in different dispersion media: air, $\mathrm{CDCl}_{3}$, and $5 \mathrm{CDCl}_{3} / 1 \mathrm{TFAA}$

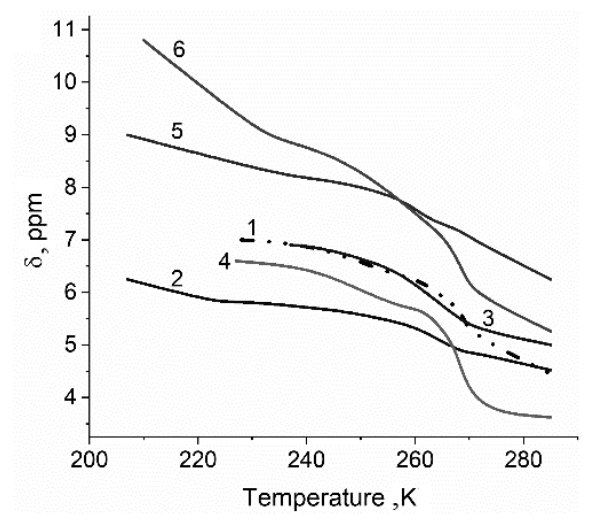

$a$

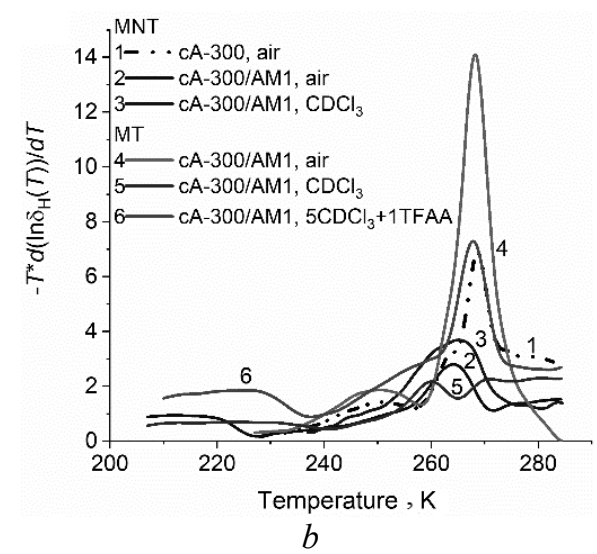

Fig. 7. (a) Dependence of the $\delta_{\mathrm{H}}$ values for unfrozen water $v s$. temperature and $(b)$ function $-T(\partial(\ln \delta(T)) / \partial T)_{\mathrm{P}} v s$. temperature (describing changes in entropy of water) for water bound in samples at constant $h=1.125 \mathrm{~g} / \mathrm{g}$ : (curve 1) cA-300 in air, non-treated (MNT) cA-300/AM1 in (2) air and (3) $\mathrm{CDCl}_{3}$, mechanically treated $(\mathrm{MT})\left(\rho_{\mathrm{b}} \approx 1.2 \mathrm{~g} / \mathrm{cm}^{3}\right) \mathrm{cA}-300 / \mathrm{AM} 1$ in $(4)$ air, (5) $\mathrm{CDCl}_{3}$, and (6) $5 \mathrm{CDCl}_{3} / 1 \mathrm{TFAA}$ 


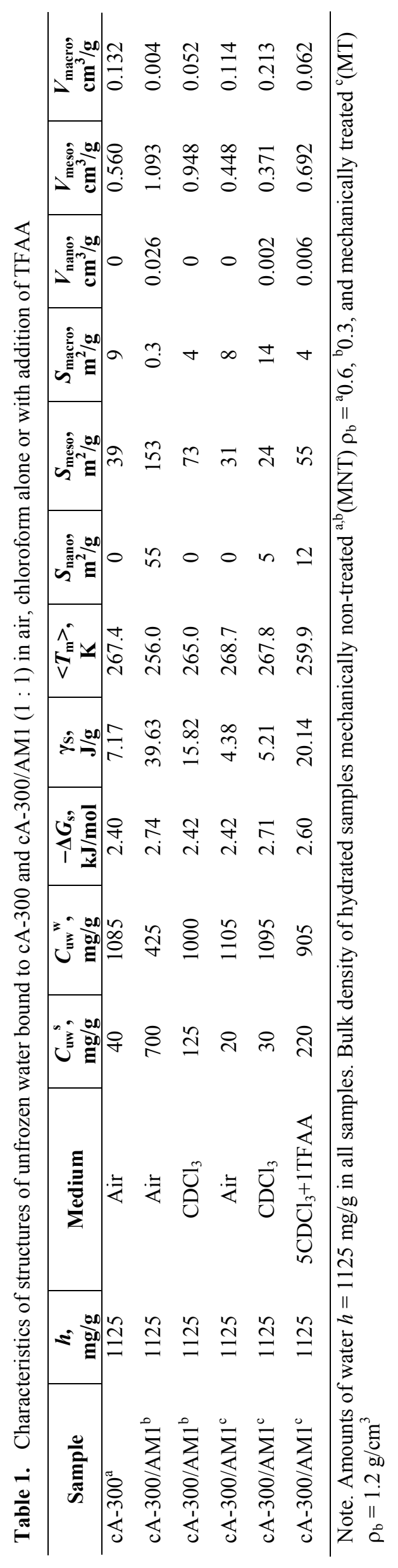



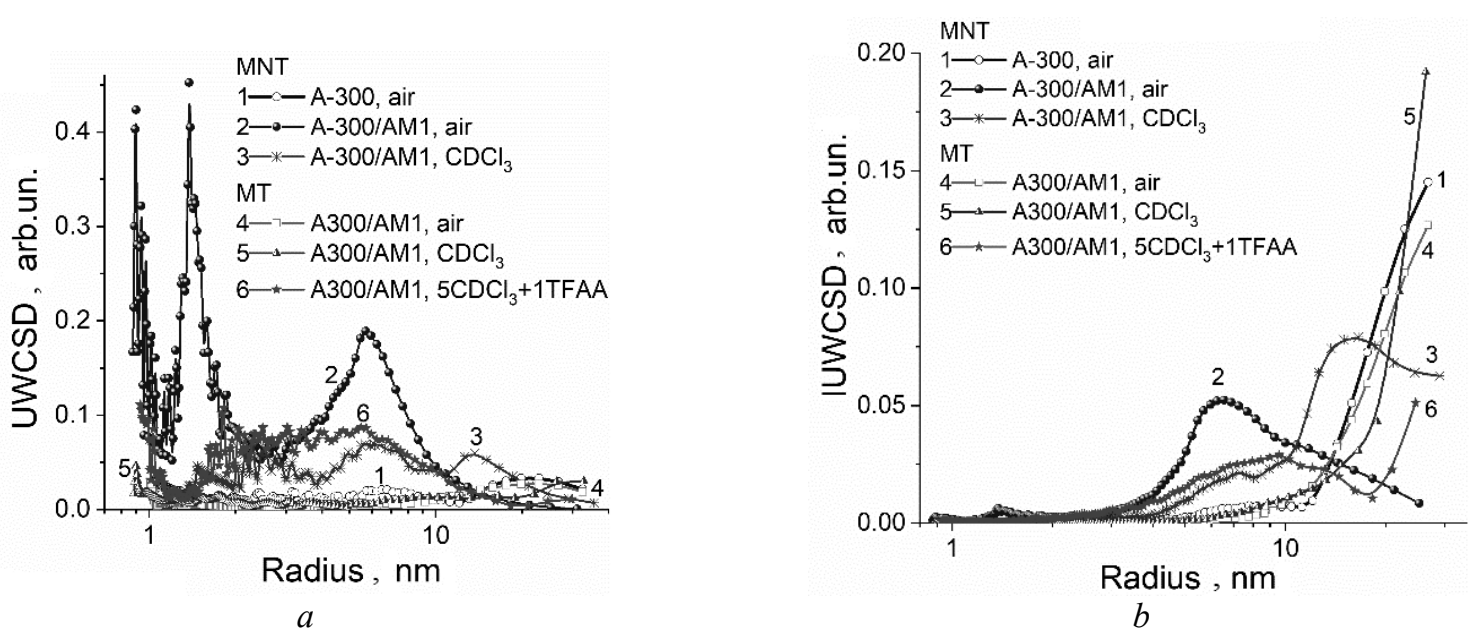

Fig. 8. Unfrozen water cluster size distributions (UWCSD) $(a)$ differential and $(b)$ incremental for water bound in samples at constant $h=1.125 \mathrm{~g} / \mathrm{g}$ (curve 1$) \mathrm{cA}-300 \mathrm{in}$ air, non-treated (MNT) cA-300/AM1 in (2) air and (3) $\mathrm{CDCl}_{3}$, mechanically treated $(\mathrm{MT})\left(\rho_{\mathrm{b}} \approx 1.2 \mathrm{~g} / \mathrm{cm}^{3}\right) \mathrm{cA}-300 / \mathrm{AM} 1$ in $(4)$ air, (5) $\mathrm{CDCl}_{3}$, and $(6)$ $5 \mathrm{CDCl}_{3} / 1$ TFAA

Addition of TFAA to chloroform leads to acid penetration into bound water, water signal shifts toward larger values (Figs. 4 and 8), and the $\gamma_{\mathrm{S}}$ value increases due to dissolution of the acid in bound water. The colligative properties of the acid/water mixture «overlap» with the confined space effects (Figs. 4-8, Table 1). However, the water clusters located in narrow voids possess lower activity as a solvent than bulk water or water located in broad pores. Therefore, compaction of the composite causes certain negative effects on the colligative properties of the acidic solution. For example, the $\gamma_{\mathrm{S}}$ value is smaller for the compacted composite located in $\mathrm{CDCl}_{3} / \mathrm{TFAA}$ in comparison to that for nontreated composite located in air, but it is slightly greater than that for $\mathrm{CDCl}_{3}$ (Table 1).

The theoretical calculations of hydrated coreshell aggregates of two types with hydrophilic or hydrophobic core and opposite shell (Fig. 9) show that in the case of hydrophilic core hydrophobic shell, water molecules are less associated (i.e. the $\delta_{\mathrm{H}}$ values are lower, Fig. 9, curve 3) than in the case of the opposite structure (curve 4). The water structure is less ordered in the case of bounding to silica clusters (Fig. 9, curves 3 and 4) than in the case of free water clusters (Fig. 9, curves 1 and 2). This disordering leads to freezing/melting point depression for bound water observed in the ${ }^{1} \mathrm{H}$ NMR experiments (Figs. 4-7).

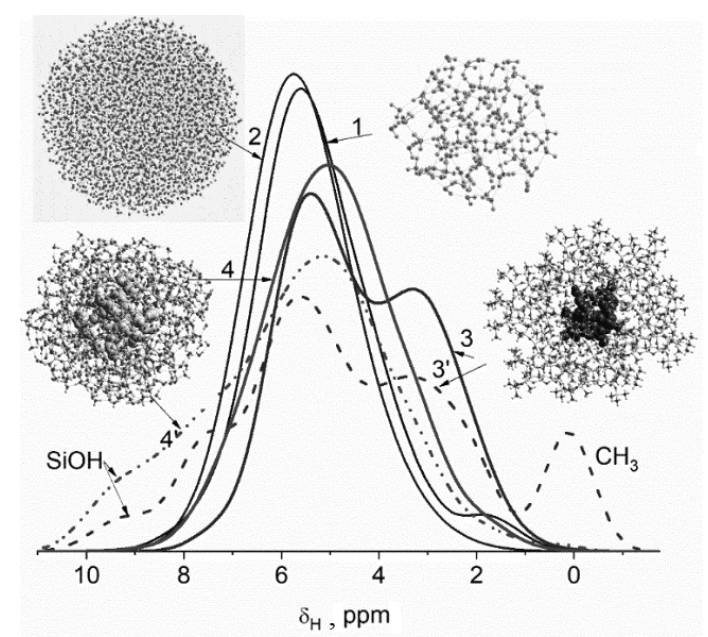

Fig. 9. Theoretically calculated ${ }^{1} \mathrm{H}$ NMR spectra of (1) $100 \omega \mathrm{B} 97 \mathrm{X}-\mathrm{D} / \mathrm{cc}-\mathrm{pVDZ}$ ), (2) $5000 \mathrm{H}_{2} \mathrm{O}$ (PM7 with a correlation function of $\delta_{\mathrm{H}} v s$. $q_{\mathrm{H}}$ ), (3) hydrophilic silica cluster with 22 tetrahedrons $\left(\mathrm{SiO}_{4 / 2}\right)$ and $16 \mathrm{OH}$ surrounded by $65 \mathrm{H}_{2} \mathrm{O}$ and six hydrophobic silica clusters with 22 tetrahedrons with 15 trimethylsilyl (TMS) groups and $\mathrm{OH}$ group (residual in place inaccessible for silane molecule to react with $\mathrm{SiOH}$ ), and (4) hydrophobic silica cluster with 8 tetrahedrons $\left(\mathrm{SiO}_{4 / 2}\right)$ and 8 TMS groups surrounded by 18 hydrophilic silica clusters with 8 tetrahedrons (each with $8 \mathrm{OH})$ and water molecules $\left(387 \mathrm{H}_{2} \mathrm{O}\right)$; spectra 3' and 4' include all $\mathrm{H}$ in the systems, but curves 3 and 4 are linked to $H$ only in water molecules 


\section{CONCLUSIONS}

The hydrophilic/hydrophobic properties of unmodified and modified nanosilicas differ in the case of the formation of hydrated composites initial and after certain mechanical loading. Additionally, changes in the dispersion media (e.g. air $\rightarrow$ hydrophobic liquid) affect the organization of water bound to nanosilicas, and changes in the organization of bound water strongly depend on the mechanical loading due to the reorganization of the particulate morphology of the materials. The formation of cA-300/AM1 composite (gentle mixing without mechanical loading) leads to a significant increase in the interaction of water (at $h=1.125 \mathrm{~g} / \mathrm{g}$ constant for all samples studied) with nanosilica since the value of free surface energy $\gamma_{\mathrm{s}}$ increases by five times. This occurs due to reorganization of water forming small nanoclusters in voids between nonporous nanoparticles in the composite, since small water nanoclusters are practically absent in cA-300 alone. After simple mechanical treatment of the composite in a mortar, more comparted composite is formed at $\rho_{\mathrm{b}} \approx 1.2 \mathrm{~g} / \mathrm{cm}^{3}$ (only by $22 \%$ lower than maximum possible true density of the system with A-300/AM1/water studied). The interaction energy of water with nanosilicas in the compacted composite is smaller (by three times for $\mathrm{CDCl}_{3}$ and ten times for air as a dispersion medium) than that for nontreated composite. Note that the effects of $\mathrm{CDCl}_{3}$ are much stronger for water bound to nontreated system than that for compacted composite. Similar effects are observed for alumina/AM1 systems. Thus, the observed influence of the hydrophobic components in complex hydrophobic/hydrophilic systems on enhancement of water binding to hydrophilic components is a general phenomenon. The effects studied are of importance on practical applications of composites with nanooxides because they demonstrate relatively simple pathways of strong changes in the properties of composites, which can be used per se or as additives, polymer fillers, etc. in more complex systems.

\title{
Вплив твердих та рідких гідрофобних сполук на характеристики води, локалізованої в адсорбційному шарі гідрофільної компоненти системи
}

\author{
В.В. Туров, В.М. Гунько, Т.В. Крупська, М.Т. Картель
}

Інститут хімії поверхні ім. О.О. Чуйка Національної академії наук України вул. Генерала Наумова, 17, Київ,03164, Украӥна, v_turov@ukr.net

Мета роботи полягала в детальному аналізі температурної і міжфазної поведінки води, яка була адсорбована на гідрофільному кремнеземі окремо чи в системах A-300/AM1 ma $\mathrm{Al}_{2} \mathrm{O}_{3} / \mathrm{AM1}$, вихідних та механічно оброблених, які були у різних дисперсійних середовищах: повітря, хлороформ, чистий чи $з$ додаванням ТФОК, методами ЯМР ${ }^{1}$ Н спектроскопї та кріопорометрії, для визначення впливу гідрофобних компонент системи на адсорбовану воду. Методами ЯМР ${ }^{1}$ Н спектроскопї та кріопорометрії було вивчено властивості суміші немодифікованого (A-300) та модифікованого (АМ1) (1:1) нанокремнеземів, а також $\mathrm{Al}_{2} \mathrm{O}_{3}$, на повітрі та у хлороформі, чистому та з додаванням ТФОК. У вихідному композиті взаємодія води з гідрофільним нанокремнеземом (гідратачія $h=1.125$ г/2) зростає і поверхнева енергія змінюється у 5 разів внаслідок реорганізації води, яка відсутня у сА-300 без АМ1. Після механічної обробки (насипна густина $\rho_{b} \approx$ $\left.1.2 \mathrm{z} \mathrm{cm}^{3}\right)$, енергія взаємодії води з нанокремнеземом зменшується (у три рази в $\mathrm{CDCl}_{3}$ та у 10 разів на повітрі) у порівнянні з необробленим композитом. Ефект $\mathrm{CDCl}_{3}$ є сильнішим для води у необробленій суміші, ніж після ї̈ механічної обробки. Було визначено, щьо вплив гідрофобних компонент у комплексних гідрофобногідрофільних системах на посилення зв'язування води з гідрофільними компонентами є загальним явищем.

Ключові слова: гідрофільні та гідрофобні нанооксиди, механічно оброблені гідратовані композити, ЯМР ${ }^{1}$ Н спектри, ефекти обмеженого простору, організація зв'язаної води, зниження температури замерзання-розмерзання 


\title{
Влияние твердых и жидких гидрофобных соединений на характеристики воды, локализированной в адсорбционном слое гидрофильной компоненты систем
}

\author{
В.В. Туров, В.М. Гунько, Т.В. Крупская, Н.Т. Картель
}

\author{
Институт химии поверхности им. А.А. Чуйко Наииональной академии наук Украины \\ ул. Генерала Наумова, 17, Киев, 03164, Украина, v_turov@ukr.net
}

\begin{abstract}
Цель работы заключалась в детальном анализе температурного и межфазного поведения воды, которая была адсорбирована на гидрофильном кремнеземе отдельно или в системах A-300/AM1 $и$ $\mathrm{Al}_{2} \mathrm{O}_{3} / \mathrm{AM1}$, исходных и механически обработанных, которые были в разных дисперсионных средах: воздух, хлороформ, чистый или с добавлением ТФУК, методами ЯМР 1 Н спектроскопии и криопорометрии, для определения влияния гидрофобных компонент системы на адсорбированную воду. Методами ЯМР $1 \mathrm{H}$ спектроскопии и криопорометрии изучены свойства смеси немодифицированного (A-300) $и$ модифицированного (AMI) (1:1) нанокремнеземов, а также $\mathrm{Al}_{2} \mathrm{O}_{3}$, на воздухе и в хлороформе, чистом и с добавлением ТФУК. В исходном композите взаимодействие воды с гидрофильным нанокремнеземом (гидратаџия $h=1.125$ г/2) растет и поверхностная энергия изменяется в 5 раз вследствие реорганизации воды, отсутствует в сA-300 без AM1. После механической обработки (насыпная плотность $\rho_{b} \approx 1.2$ г/см ${ }^{3}$ ), энергия взаимодействия воды с нанокремнеземом уменьшается (в три раза в $\mathrm{CDCl}_{3}$ и в 10 раз в воздухе) по сравнению с необработанным композитом. Эффект $\mathrm{CDCl}_{3}$ является сильнее для воды в необработанной смеси, чем после ее механической обработки. Было определено, что влияние гидрофобных компонент в комплексных гидрофобно-гидрофильных системах на усиление связывания воды с гидрофильными компонентами являются общим явлением.
\end{abstract}

Ключевые слова: гидрофильные и гидрофобные нанооксиды, механически обработанные гидратированные композиты, ЯМР ${ }^{1} H$ спектры, эффекты ограниченного пространства, организация связанной воды, понижение температуры замерзания-размерзания

\section{REFERENCES}

1. Somasundaran P. (Ed.) Encyclopedia of Surface and Colloid Science. (Third Edition, Boca Raton: Taylor \&Francis,CRC Press, 2015).

2. Bergna H.E. (Ed.) Colloidal Silica: Fundamentals and Applications. (Salisbury: Taylor \& Francis LLC, 2005).

3. Saleh K., Forny L., Guigon P., Pezron I. Dry water: From physico-chemical aspects to process-related parameters. Chem. Eng. Res. Des. 2011. 89(5): 537.

4. Degussa's «dry water» for cosmetics chemists. Focus Pigm. 2004. 8: 7.

5. Wang W., Bray C.L., Adams D.J., Cooper A.I. Methane Storage in Dry Water Gas Hydrates. J. Am. Chem. Soc. 2008. 130(35): 11608.

6. Han Z., Zhang Y., Du Z., Xu F., Li S., Zhang J. New-type gel dry-water extinguishants and its effectiveness. J. Cleaner. Prod. 2017. 166: 590.

7. Hou J., Zhou W., Bai D., Li S., Han M. Interfacial effect of cyclodextrin inclusion complex on gas adsorption kinetics of dry water emulsion. Colloids Surf. A. 2018. 544: 8.

8. Taylan O., Berberoglu H., Thermal radiation transport in a fluidized dry water system. J. Quant. Spectrosc. Radiat. Transfer. 2013. 120: 104.

9. Arab D., Kantzas A., Bryant S.L. Nanoparticle stabilized oil in water emulsions: A critical review. J. Petrol. Sci. Eng. 2018. 163: 217.

10. Shpak A.P., Gorbyk P.P. (Eds.) Nanomaterials and Supramolecular Structures. (Dordrecht: Springer, 2010).

11. Chuiko A.A. (Ed.) Medical chemistry and clinical application of silica. (Kiev: Naukova Dumka, 2003). [in Russian].

12. Gun'ko V.M., Turov V.V., Bogatyrev V.M., Zarko V.I., Leboda R., Goncharuk E.V., Novza A.A., Turov A.V., Chuiko A.A. Unusual properties of water at hydrophilic/hydrophobicinterfaces. Adv. Colloid Interface Sci. 2005. 118(1-3): 125.

13. Gun'ko V.M., Turov V.V. Nuclear Magnetic Resonance Studies of Interfacial Phenomena. (Boca Raton: CRC Press, 2013). 
14. Gun'ko V.M., Turov V.V., Myronyuk I.F., Goncharuk O.V., Pakhlov E.M., Bezruka N.A., Skwarek E., Janusz W., Blitz J.P. Interfacial phenomena at a surface of partially silylated nanosilica. J. Colloid Interface Sci. 2014. 434: 28-39.

15. Gun'ko V.M., Turov V.V., Krupska T.V., Pakhlov E.M. Behavior of water and methane bound to hydrophilic and hydrophobic nanosilicas and their mixture. Chem. Phys. Lett. 2017. 690: 25-30.

16. Gun'ko V.M., Zarko V.I., Leboda R., Chibowski E. Aqueous suspensions of fumed oxides: particle size distribution and zeta potential. Adv. Colloid Interface Sci. 2001. 91(1): 1.

17. Mitchell J., Webber J.B.W., Strange J.H. Nuclear magnetic resonance cryoporometry. Phys. Rep. 2008. $461(1): 1$.

18. Kimmich R. NMR Tomography, Diffusometry, Relaxometry. (Heidelberg: Springer, 1997.)

19. Strange J.H., Rahman M., Smith E.G. Characterization of porous solids by NMR. Phys. Rev. Lett. 1993. 71(21): 3589.

20. Mallamace F., Corsaro C., Broccio M., Branca C., González-Segredo N., Spooren J., Chen S.-H., Stanley H.E. NMR evidence of a sharp change in a measure of local order in deeply supercooled confined water. Proc. Natl. Acad. Sci. USA. 2008. 105(35): 12725.

21. Frisch M.J., Trucks G.W., Schlegel H.B., Scuseria G.E., Robb M.A., Cheeseman J.R., Scalmani G., Barone V., Mennucci B., Petersson G.A., Nakatsuji H., Caricato M., Li X., Hratchian H.P., Izmaylov A.F., Bloino J., Zheng G., Sonnenberg J.L., Hada M., Ehara M., Toyota K., Fukuda R., Hasegawa J., Ishida M., Nakajima T., Honda Y., Kitao O., Nakai H., Vreven T., Montgomery J.A., Peralta J.E., Ogliaro F., Bearpark M., Heyd J.J., Brothers E., Kudin K.N., Staroverov V.N., Keith T., Kobayashi R., Normand J., Raghavachari K., Rendell A., Burant J.C., Iyengar S.S., Tomasi J., Cossi M., Rega N., Millam J.M., Klene M., Knox J.E., Cross J.B., Bakken V., Adamo C., Jaramillo J., Gomperts R., Stratmann R.E., Yazyev O., Austin A.J., Cammi R., Pomelli C., Ochterski J.W., Martin R.L., Morokuma K., Zakrzewski V.G., Voth G.A., Salvador P., Dannenberg J.J., Dapprich S., Daniels A.D., Farkas O., Foresman J.B., Ortiz J.V., Cioslowski J., Fox D.J. Gaussian 09, Revision D.01, Gaussian. (Inc., Wallingford CT, 2013).

22. Chai J.-D., Head-Gordon M. Long-range corrected hybrid density functionals with damped atom-atom dispersion corrections. Phys. Chem. Chem. Phys. 2008. 10(44): 6615.

23. Yang K., Zheng J., Zhao Y., Truhlar D.G. Tests of the RPBE, revPBE, $\tau$-HCTHhyb, $\omega B 97 X-D$, and MOHLYP density functional approximations and 29 others against representative databases for diverse bond energies and barrier heights in catalysis. J. Chem. Phys. 2010. 132(16): 164117.

24. Marenich A.V., Cramer C.J., Truhlar D.G. Universal solvation model based on solute electron density and on a continuum model of the solvent defined by the bulk dielectric constant and atomic surface tensions. J. Phys. Chem. B. 2009. 113(18): 6378.

25. Stewart J.J.P. MOPAC2016, Stewart Computational Chemistry. 2018.

26. Stewart J.J.P. Optimization of parameters for semiempirical methods VI: more modifications to the NDDO approximations and re-optimization of parameters. J. Mol. Model. 2013. 19(1): 1.

27. Dennington R., Keith T., Millam J. GaussView, Version 5.0.9, Semichem Inc., Shawnee Mission KS, 2009.

28. Zhurko G.A., Zhurko D.A. Chemcraft (version 1.8, build b536a), 2017, www.chemcraftprog.com.

29. Pettersen E.F., Goddard T.D., Huang C.C., Couch G.S., Greenblatt D.M., Meng E.C., Ferrin T.E. UCSF Chimera - a visualization system for exploratory research and analysis. J. Comput. Chem. 2004. 25(13): 1605. 